\title{
OPINION 21
}

Conservation of the Generic Name Selenomonas von Prowazek

Von Prowazek (July 1913) proposed as a generic name Selenomonas to include a species which he described from blood smears from various African game animals (gazelle, giraffe, harness antelope) which had been shot with some escape of gut contents into the blood stream. He published 9 colored illustrations. He did not give a binary combination (did not propose a specific epithet) for the organisms he described. However, he cited the names of two organisms previously described by other authors. He noted the close resemblance of his organisms to Spirillum sputigenum Flügge (1886) and to the Ancyromonas ruminantium of Certes. Woodc ock and Lapage (November 1913) concluded that Ancyromonas ruminantium Certes (1889) was incorrectly placed in the genus Ancyromonas and proposed that it be transferred to a new genus Selenomastix, becoming Selenomastix ruminantium (Certes) Woodcock and Lapage.

Apparently the first recognition after publication of the generic name Selencmonas von Prowazek was by Simons (1920) who, in a footnote in an article on certain microonganisms present in the caecum of the guinea pig, stated that one organism found belonged in von Prowazek's Selenomonas and would be described in a later publication. Simons (1921) named this organism Selenomonas palpitans; a more complete description was published by Boskamp (1922).

Wenyon (1926) recognized the priority of Selenomonas von Prowazek over Selenomastix Woodcock and Lapage, and renamed the organism Selenomonas ruminantium (Certes) Wenyon.

The generic name Selenomonas von Prowazek apparently was validly published. Although the new species described and figured in detail was not named, two other species, Spirillum sputigenum Flügge and Ancyromonas ruminantium Certes were included together with a "description of the group."

The name of the type species of a new genus must be taken from one of the species described or indicated in the original article in which the genus is described. Inasmuch as the species Selenomonas palpitans Simons was not in von Provazek's 
list of species, the proposal by Lessel (1957) that this be recognized as the name of the type species cannot stand. Study of von Prowazek's paper does not indicate that he regarded the organism which he described as the same as Selenomonas ruminantium. This is unfortunate, for the new species was described and figured in detail. The suggestion is made in the Judicial Commission's Preliminary Statement (1955) that Selenomonas sputigena (Flügge) von Prowazek be designated as the type species. However, Boskamp (1922) apparently first used the combination $\underline{S}$. sputigena and the new combination should be ascribed to him, as Selenomonas sputigena (Flügge) Boskamp.

The following Opinion 21 was approved unanimously by the Judicial Commission and by the International Committee on Bacteriological Nomenclature at meetings held in August 1958 in Stockholm, in connection with the meeting of the VII Internationa 1 Microbiological Congress.

\section{Opinion 21}

1. The generic name Selenomonas von Prowazek 1913 was validly published with an accompanying description of the genus.

2. The species Spirillum sputigenum Flügge 1886 was characterized and adequate references to description given. The species was assigned to the genus Selenomonas.

3. Selenomonas sputigena (Flügge) Boskamp 1922 (basonym Spirillum sputigenum Flügge) is designated as the type species of Selenomonas von Prowazek.

4. The generic name Selenomonas von Prowazek 1913 is placed in the list of nomina generum conservanda.

\section{REFERENCES}

Boskamp, E. 1922. Ueber Bau, Lebensweise und Systematische Stellung von Selenomonas palpitans (Simons). Centr. Bakt. Parasitenk., Abt. I, Orig. 88:58-73.

Certes, A. 1889. Note sur les micro-organismes de la panse des ruminants. Bull. Soc. Zool. France, 14:70-73. 
B A C TER I O L OG I C A L NOMENCIATURE A N D T A X O NOMY

Flügge, C. 1886. Die Microorganismen. Leipzig. Judicial Commision. 1955. Status of the generic name Selenomonas von Prowazek. Internat1. Bull. Bact. Nomen. Tax. 5:7-12.

Lessel, E. 1957. Selenomonas von Prowazek 1913, in: Bergey's Manual of Determinative Bacteriology. 7 th ed. p. 258.

Simons, H. 1920. Eine saprophytische Oscillarie im Darm des Neerschweinchens. Centr. Bakt. Parasitenk. Abt. 2. 50: 356-368.

- 1921. Ueber Selenomonas palpitans n.sp. Centr. Bakt. Parasitenk., Abt. I, Orig., 87:50.

v on Prowazek, S. 1913. Zur Parasitologie von Westafrica. Centr. Bakt. Parasitenk., Abt. I, Orig. 88:58-73.

Wenyon, Charles Morley. 1926. Protozoology; A Manual for Medical Men, Veterinarians, and Zoologists. 2 vol. 1563 pp. London, Baillier, Tindall and Cox.

woodcock, H.M. and G. Lapage. 1913. On a remarkable type of protistan parasite. Quart. Jour. Microbiol. Sci., N.S. 59: $431-458$. 